\title{
Impact of Organizational and Family Support on Work-Life Balance: An Empirical Research
}

\author{
Subrata Banik ${ }^{1}$, Kaniz Marium Akter ${ }^{2 *} \&$ Mohammad Shahansha Molla ${ }^{3}$ \\ ${ }^{1}$ Assistant Professor, Department of Management, Mawlana Bhashani Science and Technology University, Bangladesh \\ 2Associate Professor, Department of Management, Mawlana Bhashani Science and Technology University, Bangladesh \\ ${ }^{3}$ Associate Professor, Department of Business Administration, Leading University, Sylhet, Bangladesh \\ *Corresponding author: kanizmakter@gmail.com
}

Citation: Banik, S., Akter, K.M. \& Molla, M.S. (2021). Impact of Organizational and Family Support on Work-Life Balance: An Empirical Research. Business Perspective Review 3(2), 1-13. DOI: https://doi.org/10.38157/businessperspective-review.v3i2.344

\section{Research Article}

\begin{abstract}
Purpose: Aim of this study is to examine the impact of organization and family support on an individual's work-life balance (WLB in the context of higher educational institutes (HEIs) in Bangladesh. The theoretical basis of the study is grounded on the work/family border theory of Clark (2000).

Methods: The study was conducted with a sample of 198 academicians of the (HEIs) in Bangladesh. A selfadministered questionnaire was used for data collection. SPSS version 21 and SmartPLS 3.0 software were used for data analysis. A measurement model was analyzed for assessing the reliability and validity of the research instrument. The Partial least squares structural equation model (PLS-SEM) was applied for testing the hypothesized model of the study.

Results: The results reveal that organizational support $(\beta=0.404)$ and family support $(\beta=0.269)$ significantly $(p<0.05)$ influence work-life balance with a variance $\left(R^{2}\right)$ of $32.1 \%$.

Implications: This study exposed the organizational roles in managing the conflicts of people's personal life and professional life. Findings would inspire the authorities to formulate employee-friendly organizational strategies and design WLB programs in assisting employees to manage their overall life both in the work and family domains.

Limitations: The research was limited to HEIs in Bangladesh which restricts the generalizability of its results.
\end{abstract}

Keywords: Work-life balance, Organizational support, Family support, Faculty members, Higher educational institutions

\section{Introduction}

The race of participating in the global ranking increases the requirements of academic as well as the administrative performance of the faculty members in the higher educational institutions (Abramov, Gruzdev \& Terentiev, 2019). The increased responsibilities have reduced their leisure and family time. Recently, academicians have been experienced some new challenges due to the outbreak of Covid-19 (Hammer, 2021). All the educational institutions are shut for indefinite periods. Consequently, several private universities of Bangladesh reduced the payments of their faculty members for a few months (Hasan \& Islam, 2020). It was the time when the academicians had to develop new teaching-learning processes and policies for reviving the education system, while at the same time, they had been experiencing the health crisis of their family members resulting from coronavirus infections (Hasan \& Islam, 2020; Solís García, 
Lago Urbano \& Real Castelao, 2021). To make the new teaching-learning strategy successful, they had to re-arrange their daily duties both at home and work (Solís García et al., 2021).

Higher educational institutions in Bangladesh have been playing a crucial role in adapting to the changes in the global education systems and unlocking the potential future through ensuring quality education for the development of the country (Akter \& Banik, 2019; Murad, Vanfretti, Rokonuzzaman \& Tuhin, 2017). The faculty members are directly associated with teaching, research, program designing, student counseling, and even administration (Akter \& Banik, 2019; Bhuiyan, Ahmmed \& Molla, 2009). Besides, having career advancement is also an important concerning issue of these academicians. Thus, these people have been leading a stressful professional life (Abramov et al., 2019; Ayari, 2019). On the other hand, academicians have been meeting challenges of performing dual roles at work and home (Montgomery, Panagopolou \& Benos, 2006), although, they need to have a satisfactory and balanced life for serving the students with optimum results.

Research reported that they have been experiencing conflicts between their work life and family (personal) life (Abramov et al., 2019; Babic \& Talbot, 2009), which creates stress in their overall life (Irfan \& Azmi, 2015; Meharunisa, 2019). Psychological distress, in the faculty members, was found as a consequence of an imbalanced (professional and personal) life (Kinman \& Wray, 2013), which reduces their productivity by impacting their psychological and physical health (Meharunisa, 2019). In these circumstances, people even perceive a sense of failure in work as well as at home, and the organizations experience the ultimate harmful results (Hoobler, Wayne \& Lemmon, 2009). Faculty members, in consequence, have been shown some adverse effects at work, such as absenteeism, job turnover, and emotional and/or physical illness (Jones, Burke \& Westman, 2013; Nohe, Meier, Sonntag \& Michel, 2015). These outcomes, therefore, have led to work-life balance research on academicians of Bangladeshi HEIs.

Based on the human resource management practice, literature argued that family-friendly organizational policies can assist people to reduce their work-family conflict and to manage their job duties and family responsibilities (Baral, 2019; Hammer, 2021; Solís García et al., 2021). Research indicated the significance of organizational roles for making happiness in people's professional life (Akter, Tang \& Adnan, 2021; Hammer, 2021). It can be argued that when individuals can have a peaceful professional life, they can mitigate the issues of their personal life too, through organizational assistance (Hammer, 2021; Solís García et al., 2021). That is how the term 'work-life balance' has been pronounced in today's working environment, where the term is considered as the well-being among employees and organizations to improve both employee performance and organizational efficiencies. Thereby, WLB programs are termed as an organizational initiative for building a win-win situation for organizations as well as for people (Hammer, 2021; Nayak \& Sharma, 2018).

On the other hand, an employee's personal and social life has a significant impact on his/her performance of what an organization is concerned about (Geevarghese \& Devi, 2018). Hence, some corporations design their policies by offering different family-friendly services to support employees such as flextime, job sharing, childcare, eldercare facilities, and so on (Chaudhuri, Arora \& Roy, 2020; Nayak \& Pandey, 2021). Researchers claimed that family members' support is vital in balancing an individual's professional and personal life (Baral, 2019; Putri, Amran, Suparwo, Kurniawan, Rahayu \& Suryana, 2021). Support from spouses, parents and other family members sometimes reduces excessive family responsibilities, thereby, employees can perform their job duties efficiently (Putri et al., 2021).

Therefore, both factors are crucial for academicians to resolve their work-life conflict and to manage their responsibilities in both work and personal domain. However, enough idea of how corporate WLB policies and practices, and an individual's family support could jointly impact his/her (professional and personal) life, especially in the HEIs in the South Asian country context is not found yet. Thus, this study attempts to

2 Published by Research \& Innovation Initiative Inc., registered with the Michigan Department of Licensing \& Regulatory Affairs, United States (Reg. No. 802790777). 
empirically investigate how organizational support and family support explain the work-life balance of the academicians in HEIs of Bangladesh.

Through addressing the research gap indicated above and the corresponding goal, the current study will define the roles of the educational institutions in managing academicians' life at work smoothly so that they can have enough time to respond to their personal, family, and social demands. In addition to the organizational roles, this study will also explain how their family members can assist them to enjoy their overall life by understanding their job natures and/or challenges and by sharing their personal and family duties. Further, the present study can broaden the existing knowledge by demonstrating the role of a firm's WLB initiatives and the caring family support of an individual in his/her general well-being. In light of this, it proposes a conceptual framework, by hypothesizing the relations between organizational and family support and work-life balance, which (upon validation in the next sections) will contribute to the development of the theoretical as well as practical framework of work-life balance.

\section{Literature review}

For establishing the conceptual framework of this research, Clark's (2000) work/family border (WFB) theory is adapted by demonstrating the influence of corporate support and family support on an individual's work-life balance. The WFB theory takes individual (border-crosser) preferences into account. The theory attempts to clarify the multifaceted interaction between individuals and their (professional and personal) lives and for providing the proper guidelines for achieving balance upon forecasting the possible imbalance (Clark, 2000; Ogunbor, 2021). The WFB theory defines 'balance' as an individual's satisfaction and doing better both at work and at home (Ogunbor, 2021). In the concept of 'work-life balance', both the domains of home and work have a significant influence on employees' professional and personal lives, while the organizational and family support assist them to effectively balance both their lives (Asiedu-Appiah \& Zoogah, 2019).

\subsection{Organizational support and work-life balance}

Organizational support (OS) refers to organizational (managerial) sympathetic views, and assistance received from other organizational members (e.g. supervisors and coworkers) in the context of the institutional job performance. Eisenberger, Huntington, Hutchison, and Sowa (1986) defined the term as "employees' global beliefs concerning the extent to which the organization values their contributions and cares about their well-being". Generally, an institution is responsible for providing its staff with a healthy and peaceful working life (Akter et al., 2021), whereas organizational WLB policies and practices can reduce their occupational stress and job burnout, thereby, adequate organizational support helps people to balance their professional and personal life (Asiedu-Appiah \& Zoogah, 2019; Geevarghese \& Devi, 2018; Nayak \& Sharma, 2018; Solís García et al., 2021). Institutions and departments can assist people to perform their family (personal) obligations easily as well as to be compatible with their careers (Akter et al., 2021). Research empirically revealed that the more an individual's perceived organizational support, the greater his/her balanced work-life (Putri et al., 2021). Similarly, Denson, Szelényi, and Bresonis (2017) exposed the significance of corporate support on the perceived work-life balance of the faculty members. This study was conducted in different ethnic groups of the USA by separately identifying institutional and departmental support as the determining factors for the work-life balance of the faculty members. Although the relationship between organizational support and work-life balance is empirically evident, there is a lack of its implication in the HEIs of South Asian countries. Thus, the present study attempts to extend the previous research by incorporating both the institutional and departmental support as organizational support in the context of Bangladeshi higher educational institutions. Scholars have stated that firms' policies and practices can assist employees to reduce their problems relating to their work and non-work life (Asiedu-

3 Published by Research \& Innovation Initiative Inc., registered with the Michigan Department of Licensing \& Regulatory Affairs, United States (Reg. No. 802790777). 
Appiah \& Zoogah, 2019; Baral, 2019; Denson et al., 2017; Fazal, Naz, Khan \& Pedder, 2019; Geevarghese \& Devi, 2018; Maragatham, Amudha \& Motha, 2017). Therefore, this research can propose the following hypothesis:

\section{H1: Organizational support positively influences work-life balance.}

\subsection{Family support and work-life balance}

Family support (FS) comes from an employee's parents, siblings, spouse, partner, children, and so on. Depending on the nature of the professional demands of an individual, his/her family demands may change and in some cases, family members assist him/her to solve his/her life issues (Chavan, Murthy \& Reddy, 2021). Research demonstrated that support from home/family results in employee satisfaction at work, their physical and psychological wellbeing that in turn resolves the conflicts between work and non-work life of employees (Chavan et al., 2021; French, Dumani, Allen \& Shockley, 2018). When people find family pressure instead of support, they cannot do better in their family and serve efficiently in their jobs too (Chavan et al., 2021). Reasonably, family support plays a vital role in reducing job stress, which consequences employee wellbeing (Nayak \& Sharma, 2018).

Research indicated that family support is associated with an individual's well-being and life satisfaction (Chavan et al., 2021; Schnettler, Miranda-Zapata, Lobos, Saracostti, Denegri, Lapo \& Hueche, 2018). Sharma, Gangwani, and Fryan (2019) opined that an employee with full support from the organization, but until and unless having family support cannot enjoy a balanced life. Besides, people can manage their professional as well as personal lives with the assistance of their family members (Maragatham et al., 2017). Scholars have found the influence of family/home support on the work-life balance (Chavan et al., 2021; French et al., 2018; Sharma et al., 2019; Sripo, Kaewpan, Kalampakorn \& Sillabutra, 2019). Therefore, Sripo et al. (2019) suggested 'family support' to the development of WLB programs for employees. Although previous studies provide sufficient theoretical explanation on the association between family (home) support and work-life balance, there is still a lack of empirical validation, especially in the HEIs of South Asian country context. This gap encourages the present research to make a novel attempt by addressing the work-life balance issues of the academicians in higher educational institutions of Bangladesh. Thus, the study develops the following hypothesis:

\section{H2: Family support positively influences work-life balance.}

The extant literature provides an adequate conceptual background upon which hypotheses of the study have been developed. Based on the background, a research framework is developed and presented in the form of a hypothesized research model (Figure 1), for empirical validation. The model shows the relationship between organizational support, family support, and work-life balance.

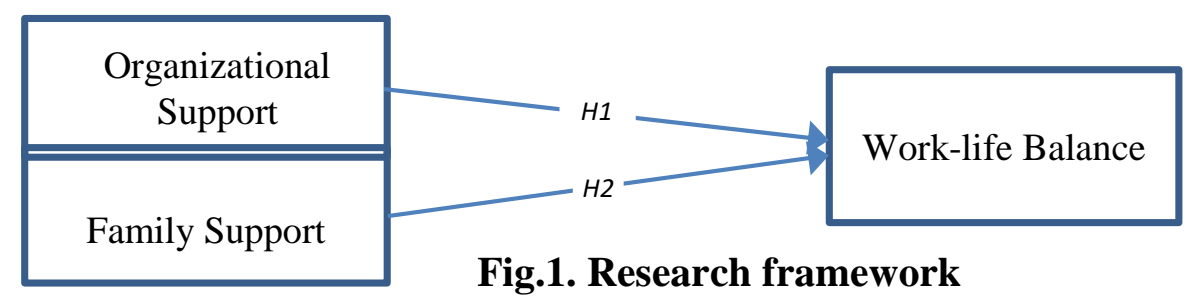




\section{Methods}

\subsection{Data collection}

The study carried out a cross-sectional field survey in order to collect data from the academicians of the HEIs of Bangladesh. There are 50 public universities and 108 private universities in Bangladesh, according to the University Grants Commission of Bangladesh (2021). Based on the convenient sampling method, 15 (public and private) universities were selected for data collection. Upon collecting the list of the faculty members from the university directory, a self-administered questionnaire was sent to them through email during June-July 2021. The questionnaire consisted of two parts: the first part contained questions relating to the respondents' background information (e.g., ownership nature of the university, respondents' age, gender, position, education, length of service, and family pattern); and the second part included questions about the constructs of this study. In all, 216 completed questionnaires were received, 18 of which were eliminated due to missing information, and thus, 198 replies were finally accepted for study.

\subsection{Measures}

The questionnaire contained a total of fifteen items that were adapted from the existing scales for measuring the constructs of the study. The adapted items were revised to make them more appreciable to the respondents. Work-life balance was measured by three items, out of which two items were taken from Joplin, Shaffer, Francesco, and Lau (2003), and one item from Denson et al. (2017). Joplin et al.'s (2003) items focus on a firm's WLB policies and practices that impact an individual's work-family life. On the other hand, Denson et al.'s (2017) item represent an individual's perception about his/her ability in balancing his/her professional life and family (personal) life. The current study considered both organizational practices as well as employee perceptions in measuring the work-life balance construct. Afterward, a seven-item scale was used for measuring organizational support, out of which four items were taken from Denson et al. (2017) and three items from Avgar, Givan, and Liu (2011). Denson et al. (2017) measured departmental and institutional support for finding the predictors of WLB of the faculty members, whereas, Avgar et al. (2011) measured stakeholders' perceived organizational support in the healthcare institutions' WLB practices that would be aimed at improved customer service and financial performance. The investigators of this research observed that when both the measurement scales were employed together for measuring the construct 'organizational support', the roles of the institution, department, mentor(s), and colleague(s) were well-defined and more understandable to the respondents.

Finally, this study measured family support by five items, out of which three items were adapted from Sharma et al. (2019) and two items from Nayak and Sharma (2018). Here, Sharma et al. (2019) developed the 'family support' measurement scale for explaining the women professionals' WLB in the service sector, while Nayak and Sharma (2018) measured the (family support) construct in examining the WLB of the academicians, who were engaged in the business schools. Since, both the scales were developed for a particular group of people, the investigators of the present study assumed that the items of both scales would comprehensively reflect 'family support' to the respondents. Responses were measured in a 5-point Likert scale, where 1 represents 'strong disagreement' and 5 represents 'strong agreement' of the respondents with the particular item.

\subsection{Data analysis techniques}

Data were processed and analyzed using SPSS 21 and SmartPLS 3.0 software. Primarily, SPSS 21 was utilized for analyzing respondents' characteristics and for evaluating the descriptive statistics of the study constructs. Afterward, by using SmartPLS 3.0, the study assessed a measurement model for analyzing the reliability and validity of the indicators. Further, the study tested the hypotheses by assessing a structural

5 Published by Research \& Innovation Initiative Inc., registered with the Michigan Department of Licensing \& Regulatory Affairs, United States (Reg. No. 802790777). 
equation model using the partial least square procedures, where a bootstrapping function of 2000 resamples was generated.

\section{Results}

\subsection{Demographic analysis}

The sample of this study mostly was from public universities representing 65.2 percent, while the rest of them were from private universities representing 34.8 percent. The respondents comprised 61.6 percent males and 38.4 percent females. In terms of the respondents' positions, 24.2 percent were lecturers, 35.4 percent were assistant professors, 19.7 percent were associate professors, and 20.7 percent were professors. Respondents mostly were found in the 31 to 40 years age group ( 38.4 percent), followed by the 24 to 30 years age group (30.8 percent), 41 to 50 years age group (14.1 percent), 51 to 60 years age group (13.6 percent), and above 60 years age group ( 3 percent). Among them, the majority of the respondents were married representing 77.3 percent, while 21.7 percent of respondents were unmarried, and 1 percent of respondents were separated.

In terms of the highest level of education, most of the respondents had a master's degree representing 59.6 percent, while 4 percent had M.Phil, 33.8 percent had Ph.D., and 2.5 percent had a post-doctoral degree. The largest group of participants (47 percent) had 6 to 15 years of working experience, while 29.8 percent had 0 to 5 years, 14.6 percent had 16 to 25 years, 5.6 percent had 26 to 35 years, and 3 percent had more than 35 years of experience. Moreover, the respondents belonged to different types of families where other family members had different types of (non-)professional backgrounds. For example, 37.9 percent of respondents were leading a single career life, that is, s/he was the only one earning member of the family. Additionally, 42.4 percent were leading dual-career life (another family member had professional background), and 19.7 percent were leading multiple career life (two or more persons had professional background). Finally, the majority of the respondents (30.8 percent) had 2 dependent members in their family, while 18.2 percent had 3 dependents, 17.7 percent had 1 dependent, 13 percent had 4 dependents, 12.2 percent had 5 dependents, 6.6 percent had 6 dependents, 1 percent had 7 dependents, and 0.5 percent had 9 dependents.

\subsection{Descriptive and correlation analysis}

The study undertook a descriptive analysis of all the three constructs (work-life balance, organizational support, and family support) for getting the mean and standard deviation scores. A mean score closer to 5 indicates the high agreement, whereas a score nearer to 1 indicates the low agreement of the respondents as their replies were collected on a 5-point scale. All the constructs of this study scored above 3 indicating the consistency of the results. Among the data, family support was found to have the highest mean score of 4.097, followed by work-life balance (3.685), and organizational support (3.527). Further, the lower (than 1) dispersion value in the case of all the constructs indicated the satisfactory outcome of the study. In this study, family support had a lower standard deviation with a value of 0.462 , followed by work-life balance (0.551), and organizational support (0.562).

The study then conducted a correlation analysis to look at the coefficients between the constructs (worklife balance, organizational support, and family support). The correlation coefficients confirmed that the variables are significantly correlated $(\mathrm{p}<0.01)$ with each other. The highest correlation was found $(0.442)$ between organizational support and work-life balance. Other significant correlations were observed between family support and work-life balance (0.355) and between organizational support and family support (0.326). Table 1 displays the mean, standard deviation, and correlation coefficients for all the constructs.

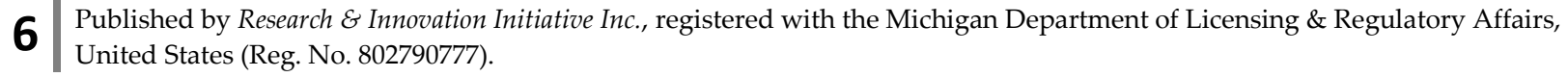


Table 1: Descriptive statistics and correlation coefficients

\begin{tabular}{|lccccc|}
\hline Constructs & Mean & $\begin{array}{c}\text { Std. } \\
\text { Deviation }\end{array}$ & $\begin{array}{c}\text { Work-life } \\
\text { Balance }\end{array}$ & $\begin{array}{c}\text { Organizational } \\
\text { Support }\end{array}$ & $\begin{array}{c}\text { Family } \\
\text { Support }\end{array}$ \\
\hline Work-life Balance & 3.685 & 0.551 & 1 & & \\
\hline Organizational Support & 3.527 & 0.562 & $0.442^{* *}$ & 1 & 1 \\
\hline Family Support & 4.097 & 0.462 & $0.355^{* *}$ & $0.326^{* *}$ & 1 \\
\hline
\end{tabular}

Note: $* *$ Correlation is significant at the 0.01 level (1-tailed)

\subsection{Measurement model assessment}

The study carried out a confirmatory factor analysis for assessing the reliability and validity of the measurement scales of the constructs. The values of the measurement model are displayed in Table 2 and Table 3.

\subsubsection{Convergent validity}

By following Chin's (1998) recommendation, this study evaluated the convergent validity through observing the values of factor loadings, composite reliability (CR), Cronbach's alpha $(\alpha)$, and average variance extracted (AVE). The values of CR, $\alpha$, and AVE of all the constructs are exhibited in Table 2 (Figure 2). The factor loadings higher than the threshold value (0.5) were kept (Hair, Black, Babin \& Anderson, 2010) (Appendix). Further, composite reliability and Cronbach's alpha met the threshold value of (0.7), and the average variance extracted met the threshold value of 0.5 for all the constructs. Therefore, these results indicated the reliability and convergent validity of the constructs.

Table 2: Results of reliability and convergent validity

\begin{tabular}{|lccc|}
\hline \multicolumn{1}{|c}{ Construct } & $\boldsymbol{\alpha}$ & CR & AVE \\
\hline Work-life Balance & 0.733 & 0.848 & 0.651 \\
\hline Organizational Support & 0.848 & 0.875 & 0.501 \\
\hline Family Support & 0.796 & 0.837 & 0.511 \\
\hline
\end{tabular}

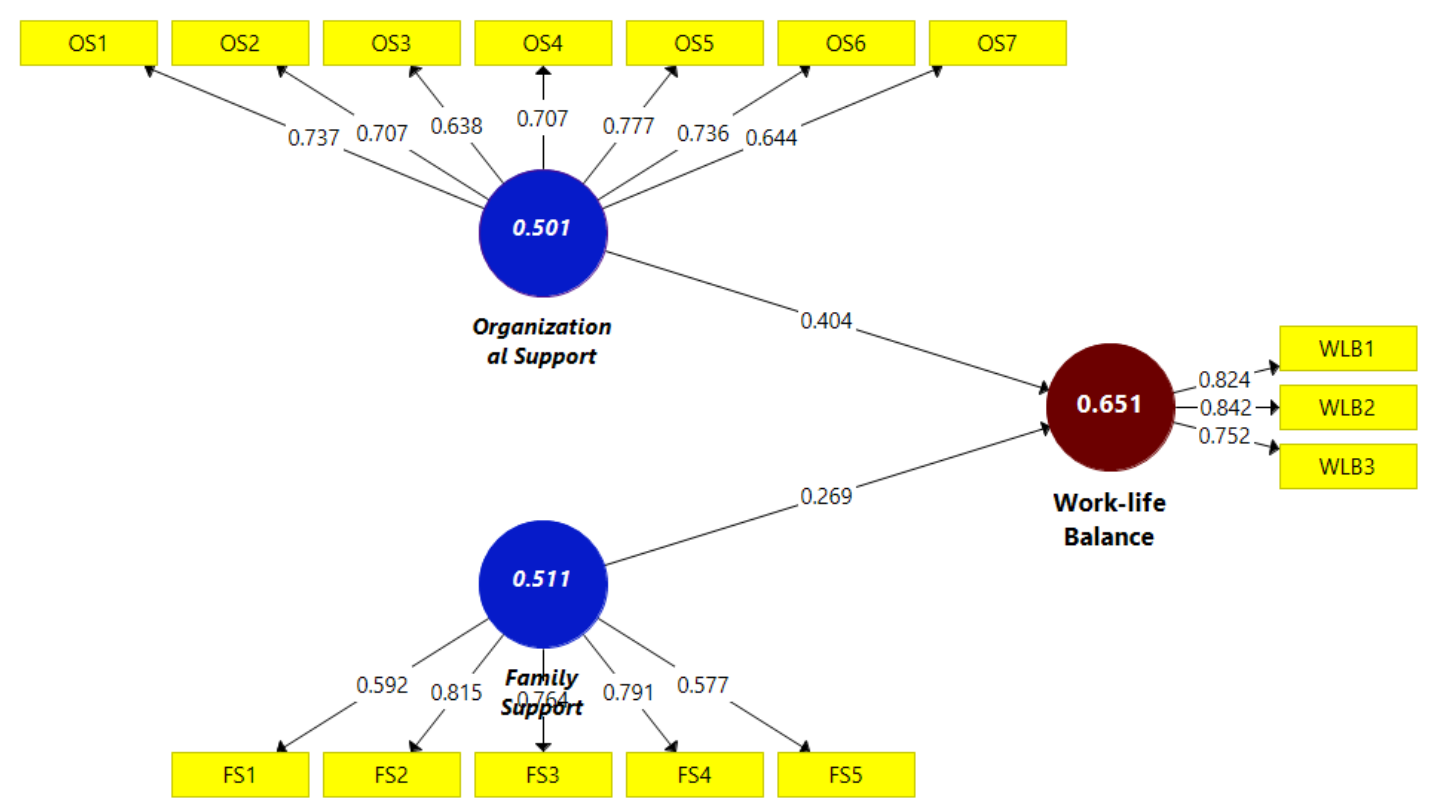

Fig.2. Measurement model

7 Published by Research \& Innovation Initiative Inc., registered with the Michigan Department of Licensing \& Regulatory Affairs, United States (Reg. No. 802790777). 


\subsubsection{Discriminant validity}

To assess the discriminant validity of the model, the study used cross-loadings of the indicators and the Fornell-Larcker criterion (Hair, Hult, Ringle \& Sarstedt, 2017). The result of the cross-loading (Appendix A) indicated that all indicators load high on their own constructs but low on the other constructs. It indicates discriminant validity is achieved as the constructs are distinctly different from each other. Also, Table 3 indicates that all the constructs exhibit sufficient and satisfactory discriminant validity (Fornell \& Larcker, 1981) since the square root of AVE (diagonal) was higher than the correlations (off-diagonal) of each construct. Hence, the measurement model of this study is considered satisfactory.

Table 3: Results of discriminant validity

\begin{tabular}{|lccc|}
\hline \multicolumn{1}{|c}{ Construct } & Work-life Balance & Organizational Support & Family Support \\
\hline Work-life Balance & $(0.807)$ & & \\
\hline Organizational Support & 0.509 & $(0.708)$ & \\
\hline Family Support & 0.428 & 0.392 & $(0.715)$ \\
\hline
\end{tabular}

Note: Values in parentheses represent the square root of AVE, and other entries represent the correlations

\subsection{Structural equation model analysis}

The study subsequently tested the hypotheses using the bootstrapping function and the results were exhibited in Table 4. As per the path coefficients (Figure 2), two hypothesized relationships $\mathrm{H} 1(\mathrm{t}=$ 4.513), and $\mathrm{H} 2(\mathrm{t}=3.154)$ were found to have a $\mathrm{t}$-value greater than 1.645 (one-tailed). So, both the relationships are significant at 5\% level of significance (Hair et al., 2017). Hypothesis $1(\beta=0.404, p<$ 0.05 ) indicated that organizational support significantly influences work-life balance. Also, hypothesis 2 showed that family support $(\beta=0.269, \mathrm{p}<0.05)$ has a strong impact on work-life balance. So, hypothesis 1 and hypothesis 2 were accepted.

Table 4: Results of hypotheses testing

\begin{tabular}{|lccccccc|}
\hline Hypothesis & Path & Std. Beta & Std. Error & t-value & p-value & Decision & $\mathbf{R}^{\mathbf{2}}$ \\
\hline H1 & OS $\rightarrow$ WLB & 0.404 & 0.089 & 4.513 & $0.000^{* *}$ & Accepted & $\mathbf{0 . 3 2 1}$ \\
\hline H2 & FS $\rightarrow$ WLB & 0.269 & 0.085 & 3.154 & $0.001^{* *}$ & Accepted & \\
\hline \multicolumn{7}{c}{ Note: Level of significance $\mathrm{p}<0.05^{* *}$} \\
\end{tabular}

Note: OS = Organizational support, FS = Family support, WLB = Work-life balance

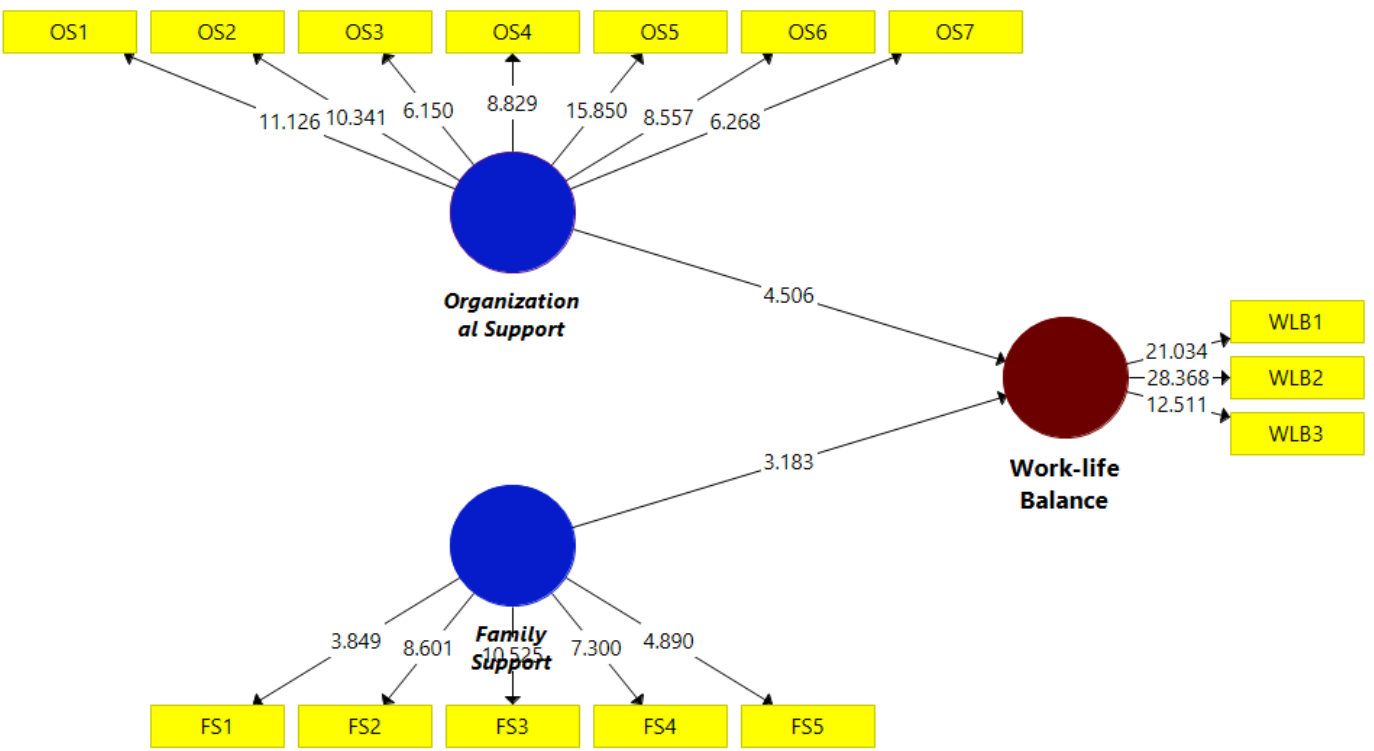

Fig.3. Bootstrapping results 
The results suggested that both organizational and family support have significant effects on work-life balance. Both the exogenous constructs (organizational support and family support) explained $32.1 \%$ of the variance in work-life balance (Figure 4$)$. The value of $\mathrm{R}^{2}(0.321>0.26)$ indicated a substantial model (Cohen, 1988).

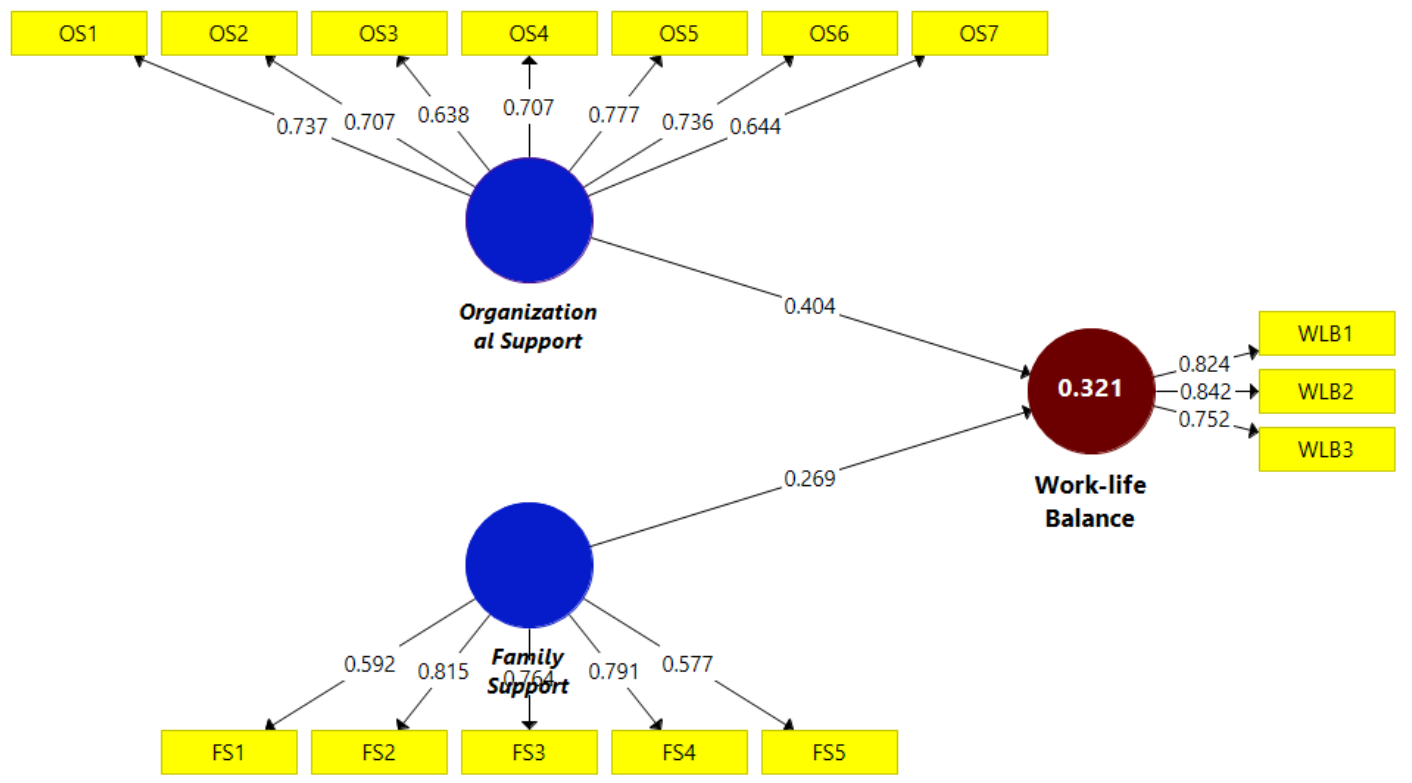

Fig.4. Results of $\mathbf{R}^{2}$

\section{Discussion}

This study aimed to investigate the influence of organizational and family support on the work-life balance of the faculty members in the higher educational institutions of Bangladesh. A cross-sectional survey was carried out among the academicians. The results indicated the different demographic characteristics of the faculty members that also might affect their work-life balance. For instance, faculty members' marital status, the nature of their family member's career, and the number of the dependent members directly affect their personal (family) life. On the other hand, the nature of the institution's ownership, faculty members' education, academic position (job rank), and length of experience influence their professional life. Both the personal (family) and organizational factors assert people to act differently in managing their personal and professional life issues.

Besides, the results presented two key findings aligning with the research hypotheses. Firstly, the results confirmed that organizational support $(\mathrm{H} 1)$ has a significant influence on faculty members' work-life balance. The finding is in line with the literature exposing that corporate policies and practices can play a significant role in managing people's personal and professional life (Asiedu-Appiah \& Zoogah, 2019; Baral, 2019; Denson et al., 2017; Fazal et al., 2019; Geevarghese \& Devi, 2018). The previous studies exhibited how organizational initiatives can resolve the work-life conflicts of people by assisting them in efficiently managing their professional life as well as in bringing peace to their personal life (Putri et al., 2021; Solís García et al., 2021). Secondly, a significant influence of family support on an individual's work-life balance (H2) was exposed in this study. This finding supports the prior similar research that emphasized the support from family/home as a predictor of people's work-life balance (Chavan et al., 2021; French et al., 2018; Sharma et al., 2019; Sripo et al., 2019). Family members' holistic concern can assist people in meeting their job demands and career challenges, thereby, they can manage their professional life, even get rid of the occupational stress when individuals have their family support.

9 Published by Research \& Innovation Initiative Inc., registered with the Michigan Department of Licensing \& Regulatory Affairs, United States (Reg. No. 802790777). 


\section{Implications}

This study designed a broad model by valuing the significance of corporate and family support and their impact on the work-life balance of people. Besides, the study integrated both work and non-work variables for explaining the work-life balance of the academicians in the HEIs that only a few studies investigated. Therefore, the detailed results of this study will undoubtedly gain great interest to researchers as well as practitioners. For instance, the findings demonstrated the significance of organizational and family support in balancing people's work-life that can inspire the managers to develop effective organizational strategies for assisting the employees to manage their overall life. If the organizations can formulate such familyfriendly strategies, people will find collegiality in the work environment where managers and colleagues will act as mentors. Thus, corporations will facilitate employees to enjoy personal/family life and overall life, which in turn will cause improved employer-employee relations. In consequence, employees will show affirmative attitudes towards jobs that will result in organizational success.

\section{Conclusion}

The study concludes that work-life balance is significant for the academicians of higher educational institutions to enjoy both their professional and personal/family lives. For enjoying a well-balanced life, individuals need assistance from their organizations as well as their home. When organizational support and family support are coupled with work-life balance, people will show positive attitudes towards job and home equally, which ultimately will impact organizational success. Institutions can strengthen employeremployee-coworker relations, enrich employees' family/personal life, and improve their physical as well as mental health through emphasizing the aforementioned constructs. Therefore, if organizations develop employee-friendly organizational policies and practices, people can solve their family/personal problems with the assistance of their managers and colleagues, while they can also perform the job duties with the support of the family members.

This study attempted to integrate the work and non-work forces that can be taken into consideration to design the WLB programs in the organization. Since faculty members are the critical factors in any educational institution, both their professional and personal life should be properly valued and cared for. It is indispensable to develop and implement effective organizational policies for assisting employees in enjoying their overall life. Thus, this research focuses on the organizational role to confirm the empirical validation and to provide meaningful insights to enhance the existing knowledge of work-life balance in higher educational institutions, specifically in the South Asian country context.

\section{Limitations and future research direction}

Although this research has demonstrated significant results on work-life balance, it encountered some limitations too. Firstly, this research was conducted in higher educational institutions. Future research may incorporate diversified samples from other industries for the generalizability of the findings. Secondly, this study considered a single country context (Bangladesh). The scope can be broadened in future research by integrating the higher educational institutions of multi-country (developed, developing, and underdeveloped countries) and/or other South Asian countries because people's work-life patterns and managerial practices vary substantially country-to-country. In future research, the impact of the Covid-19 pandemic on the academician's work and non-work life would be investigated. Finally, future research would employ employees' family factors (e.g. family members' professional background, number of dependents, marital status) as moderating variables in explaining work-life balance. 
Authors' Contributions: Subrata Banik and Kaniz Marium Akter conceived the idea and analyzed data. All authors actively took part in collecting data and writing the article.

Conflict of Interest: The authors declare no conflict of interest.

\section{REFERENCES}

Abramov, R. N., Gruzdev, I. A., \& Terentiev E. A. (2019). Work-life balance and sources of stress for the academic staff in Russian research universities. Monitoring of Public Opinion: Economic and Social Changes, 3, 8-26. https://doi.org/10.14515/monitoring.2019.3.02

Akter, K. M., \& Banik, S. (2019). Knowledge Management Practices of Universities in Bangladesh: Lecturers' Perception. Journal of Accounting Research, Organization, and Economics, 2(1), 54-62.

Akter, K. M., Tang, S. M., \& Adnan, Z. (2021). Transformational leadership and quality of work life: A mediation model of trust climate. Problems and Perspectives in Management, 19(4), 161-174. doi:10.21511/ppm.19 (4).2021.14

Asiedu-Appiah, F., \& Zoogah, D. B. (2019). Awareness and usage of work-life balance policies, cognitive engagement, and perceived organizational support: A multilevel analysis. Africa Journal of Management, 5(2), 115-137. https://doi.org/10.1080/23322373.2019.1618684

Avgar, A. C., Givan, R. K., \& Liu, M. (2011). A balancing act: Work-life balance and multiple stakeholder outcomes in hospitals. British journal of industrial relations, 49(4), 717-741. https://doi.org/10.1111/j.1467-8543.2010.00839.x

Ayari, A. (2019). Stress in the Workplace: Women Academics in the University of Bahrain. Journal of Advanced Research in Dynamical and Control Systems, 11(4), 2582-2586.

Babić, S., \& Talbot, K. (2019). Third-Age University Teachers in Language Education: Navigating the Boundaries of Work-Life Balance and Retirement. In Challenging Boundaries in Language Education (pp. 183-198). Springer, Cham.

Baral, R. (2019). Comparing the situation and person-based predictors of work-family conflict among married working professionals in India. Equality, Diversity, and Inclusion: An International Journal, 39(5), 479-495. https://doi.org/10.1108/EDI-01-2019-0040

Bhuiyan, B. A., Ahmmed, K., \& Molla, M. S. (2009). A theoretical framework for quality assurance in higher education in Bangladesh. Journal of Business, Society and Science, 1(1), 27-51.

Chaudhuri, S., Arora, R., \& Roy, P. (2020). Work-Life balance policies and organisational outcomes - a review of literature from the Indian context. Industrial and Commercial Training, 52(3), 155-170. https://doi.org/10.1108/ICT-01-2019-0003

Chavan, R., Murthy, D. S., \& Reddy, I. T. N. (2021). Work \& family stress on work-life balance of corporate hospital doctors. Journal of Management (IJM), 12(4), 138-149. DOI: 10.34218/IJM.12.4.2021.014

Chin, W. (1998). Issues and opinions on structural equation modeling. MIS Quarterly, 22(1), 7-16.

Clark, S. C. (2000). Work/family border theory: A new theory of work/family balance. Human Relations, 53(6), 747-770. https://doi.org/10.1177/0018726700536001

Cohen, J. (1988). Statistical power analysis for the behavioral sciences. Statistical power analysis for the behavioral sciences (2nd ed.), Hillsdale, NJ: Lawrence Erlbaum Associates.

Denson, N., Szelényi, K., \& Bresonis, K. (2018). Correlates of work-life balance for faculty across racial/ethnic groups. Research in Higher Education, 59(2), 226-247. https://doi.org/10.1007/s11162-017-9464-0

Eisenberger, R., Huntington, R., Hutchison, S., \& Sowa, D. (1986). Perceive organizational support. Journal of Applied Psychology, 71(3), 500-507.

Fazal, S., Naz, S., Khan, M. I., \& Pedder, D. (2019). Barriers and enablers of women's academic careers in Pakistan. Asian Journal of Women's Studies, 25(2), 217-238. https://doi.org/10.1080/12259276.2019.1607467

Fornell, C., \& Larcker, D. (1981). Evaluating structural equation models with unobservable variables and measurement errors. Journal of Marketing Research, 18(1), 39-50. https://doi.org/10.1177/002224378101800104

French, K. A., Dumani, S., Allen, T. D., \& Shockley, K. M. (2018). A meta-analysis of work-family conflict and social support. Psychological Bulletin, 144(3), 284-314. https://doi.org/10.1037/bul0000120

Geevarghese, \& Devi, K. K. S. (2018). Impact of Organizational Support on Executives' Personal and Social Life: An Empirical Study among the Executives of Large Scale Public Sector Manufacturing Organizations across India. Journal of Computational and Theoretical Nanoscience, 15(11-12), 3576-3579. https://doi.org/10.1166/jctn.2018.7667

Hair, J. F., Black, W. C., Babin, B. J., \& Anderson, R. E. (2010). Multivariate Data Analysis (7th ed.): Prentice-Hall: Upper Saddle River.

Hair, J. F., Hult, G. T. M., Ringle, C., \& Sarstedt, M. (2017). A primer on partial least squares structural equation modeling (PLS-SEM). USA: Sage publications Inc. 
(C) Banik, Akter \& Molla

Hammer, E. (2021). HRD interventions that offer a solution to the work-life conflict. Advances in Developing Human Resources, 23(2), 142-152. https://doi.org/10.1177/1523422321991192

Hasan, Z., \& Islam, K. A. (2020). Academic, Financial and Administrative Issues of Online Teaching during Corona Pandemic: The Scenario of Private Universities in Bangladesh. International Journal of Accounting \& Finance Review, 5(1), 116122. https://doi.org/10.46281/ijafr.v5i1.630

Hoobler, J. M., Wayne, S. J., \& Lemmon, G. (2009). Bosses' perceptions of family-work conflict and women's promotability: Glass ceiling effects. Academy of management journal, 52(5), 939-957. https://doi.org/10.5465/amj.2009.44633700

Irfan, A., \& Azmi, F. T. (2015). Work-Life Balance among Teachers: An Empirical Study. IOSR Journal of Business and Management, 17(2), 1-11.

Joplin, J. R., Shaffer, M. A., Francesco, A. M., \& Lau, T. (2003). The macro-environment and work-family conflict: Development of a cross-cultural comparative framework. International Journal of Cross-Cultural Management, 3(3), 305-328. https://doi.org/10.1177/1470595803003003004

Jones, F., Burke, R. J., \& Westman, M. (2013). Work-life balance: A psychological perspective. Hove: Psychology Press.

Kinman, G., \& Wray, S. (2013). Higher stress: A survey of stress and well-being among staff in higher education. London, UK: University and College Union.

Maragatham, B., Amudha, R., \& Motha, L. C. S. (2017). Work-life balance of married women teachers in higher education in Kumbakonam town. International Journal of Economic Research, 14(5), 329-337.

Meharunisa, S. (2019). Work-Life Balance and Job Stress among Female Faculties in India's Higher Education Institutions. International Journal of Recent Technology and Engineering, 8(2), 846-852. DOI: 10.35940/1jrte.B1139.0982S1119

Montgomery, A. J., Panagopolou, E., \& Benos, A. (2006). Work-family interference as a mediator between job demands and job burnout among doctors. Stress and Health, 22(3), 203-212. https://doi.org/10.1002/smi.1104

Murad, M. A. A., Vanfretti, L., Rokonuzzaman, M., \& Tuhin, R. A. (2017). Enhancing engineering studies in developing countries using Open Modelica. In 2017 4th International Conference on Advances in Electrical Engineering, (pp. 153158). IEEE. DOI: 10.1109/ICAEE.2017.8255345

Nayak, A., \& Pandey, M. A. (2021). Study on Moderating Role of Family-Friendly Policies in Work-Life Balance. Journal of Family Issues. DOI: 10.1177/0192513X211030037

Nayak, P., \& Sharma, N. (2018). Managing Faculty's Work-Life Balance in Indian Business Schools. Teorija in Praksa, 55(3), 604-621.

Nohe, C., Meier, L. L., Sonntag, K., \& Michel, A. (2015). The chicken or the egg? A meta-analysis of panel studies of the relationship between work-family conflict and strain. Journal of Applied Psychology, 100, 522-536.

Ogunbor, O. N. (2021). A study of work-family balance policies and practices for returning nursing mothers in the Nigerian banking industry. Doctoral dissertation, University of Salford.

Putri, A., Amran, A., Suparwo, A., Kurniawan, A., Rahayu, Y. S., \& Suryana, S. (2021). The Importance of Perceived Organizational Support and Work from Home to increase Work-Life Balance during the Covid-19 Pandemic. Asia Pacific Journal of Management and Education (APJME), 4(3), 10-21. https://doi.org/10.32535/apjme.v4i3.1262

Schnettler, B., Miranda-Zapata, E., Lobos, G., Saracostti, M., Denegri, M., Lapo, M., \& Hueche, C. (2018). The mediating role of family and food-related life satisfaction in the relationships between family support, parent work-life balance, and adolescent life satisfaction in dual-earner families. International journal of environmental research and public health, 15(11), 1-18. https://doi.org/10.3390/ijerph15112549

Sharma, S., Gangwani, S., \& Fryan, L. H. (2019). Work-Life Balance of Working Women Professionals: Scale Development. International Journal of Scientific \& Technology Research, 8(11), 3504-3511.

Solís García, P., Lago Urbano, R., \& Real Castelao, S. (2021). Consequences of COVID-19 Confinement for Teachers: FamilyWork Interactions, Technostress, and Perceived Organizational Support. International Journal of Environmental Research and Public Health, 18(21), 11259. https://doi.org/10.3390/ijerph182111259

Sripo, N., Kaewpan, W., Kalampakorn, S., \& Sillabutra, J. (2019). Factors Related to Work-Life Balance among Occupational Health Nurses in Thailand. Indian Journal of Public Health Research and Development, 10(5), 1492-1498.

(C) 2021 by the authors. Licensee Research E Innovation Initiative Inc., Michigan, USA. This article is an open-access article distributed under the terms and conditions of the Creative Commons Attribution (CC BY) license (http://creativecommons.org/licenses/by/4.0/). 
Appendix

Results of convergent validity and discriminant validity: Outer loadings and cross-loadings

\begin{tabular}{|c|c|c|c|c|c|}
\hline \multicolumn{2}{|r|}{ Indicators/items } & \multirow{2}{*}{$\begin{array}{c}\text { Outer } \\
\text { loadings }\end{array}$} & \multicolumn{3}{|c|}{ Cross-loadings } \\
\hline & & & WLB & OS & FS \\
\hline WLB1 & $\begin{array}{l}\text { I have been able to find the right balance, for me, between } \\
\text { my professional life and my personal/family life. }\end{array}$ & 0.824 & 0.824 & 0.389 & 0.308 \\
\hline WLB2 & $\begin{array}{l}\text { The work-life balance practices in my organization are } \\
\text { adequate in helping me meet my family responsibilities. }\end{array}$ & 0.842 & 0.842 & 0.459 & 0.406 \\
\hline WLB3 & I am well able to meet my family and work demands. & 0.752 & 0.752 & 0.377 & 0.309 \\
\hline OS1 & $\begin{array}{l}\text { My institution does what it can to make personal/family } \\
\text { obligations and an academic career compatible. }\end{array}$ & 0.737 & 0.459 & 0.737 & 0.196 \\
\hline OS2 & $\begin{array}{l}\text { I have collegial and supportive colleagues, who help me } \\
\text { to boost my career/academic life. }\end{array}$ & 0.707 & 0.326 & 0.707 & 0.143 \\
\hline OS3 & I get mentoring (from someone) in my department. & 0.638 & 0.201 & 0.638 & 0.280 \\
\hline OS4 & $\begin{array}{l}\text { Colleagues do what they can to make my personal/family } \\
\text { obligations and an academic career compatible. }\end{array}$ & 0.707 & 0.259 & 0.707 & 0.324 \\
\hline OS5 & $\begin{array}{l}\text { My university authority is committed to helping } \\
\text { academicians balance their work and home life. }\end{array}$ & 0.777 & 0.543 & 0.777 & 0.369 \\
\hline OS6 & $\begin{array}{l}\text { My departmental head/chairperson helps me find a good } \\
\text { work-life balance. }\end{array}$ & 0.736 & 0.244 & 0.736 & 0.350 \\
\hline OS7 & $\begin{array}{l}\text { I can approach my chairperson/head to talk openly about } \\
\text { flexible working. }\end{array}$ & 0.644 & 0.211 & 0.644 & 0.340 \\
\hline FS1 & My family supports all aspects of my job. & 0.592 & 0.101 & 0.061 & 0.592 \\
\hline FS2 & My family members listen to my job-related problems. & 0.815 & 0.257 & 0.271 & 0.815 \\
\hline FS3 & $\begin{array}{l}\text { I am satisfied with the amount of time (I am allotted) for } \\
\text { performing family responsibilities. }\end{array}$ & 0.764 & 0.483 & 0.421 & 0.764 \\
\hline FS4 & My family supports me at times of stress in my job. & 0.791 & 0.249 & 0.303 & 0.791 \\
\hline FS5 & $\begin{array}{l}\text { My family recognizes and celebrates my job-related } \\
\text { successes. }\end{array}$ & 0.577 & 0.147 & 0.043 & 0.577 \\
\hline
\end{tabular}

